\title{
Banding patterns in plant chromosomes. III. Dactylis glomerata subsp. aschersoniana (Graebner) Thell. from Poland
}

\author{
MARTA MIZIANTY
}

\begin{abstract}
Institute of Botany, Polish Academy of Sciences, Lubicz 46, 31-512 Kraków, Poland
\end{abstract}
(Received August 27, 1984. Revision accepted: December 3, 1984)

\begin{abstract}
The present paper presents part of the author's studies on the variability of the genus Dactylis from Poland. The karyotypes and Giemsa heterochromatin banding patterns of three population samples of Dactylis glomerata subsp. aschersoniana (Graebner) Thell. $(2 n=14)$ from Poland were studied in detail.
\end{abstract}

Key words: Dactylis glomerata subsp. aschersoniana (Graebner) Thell., Giemsa banding patterns

\section{INTRODUCTION}

In the genus Dactylis diploid $(2 n=14)$ and tetraploid $(2 n=28)$ taxa occur, exceptionally Borrill and Jones (1961) discovered a hexaploid taxon $(2 n=42)$ in material from Cyrenaica and from Western Egypt.

The diploids occur in particular geographical areas (Stebbins and Zohary 1959), but tetraploids are widely distributed in northern temperate regions. The tetraploid complex contains a great number of ecotypes. Sometimes the diploids and tetraploids are sympatric. Between these chromosome races there occur natural triploid hybrids (Müntzing 1937).

The biosystematic and evolutionary relationships between diploids and tetraploids pose a great problem for taxonomists (Borrill 1961, Doroszewska 1961, 1963, Stebbins and Zohary 1959 and many others). It seems that cytological and especially karyological studies might contribute to a better understanding of these connections.

The studies of banding patterns were very useful in the determination of phylogenetic relationships in some taxa, and during recent years such investigations have dealt with a large number of plant genera and species (Fiskesjö 1975, Lavania and Sharma 1980, 1983, Mizianty 1982). 
In the genus Dactylis from the south-eastern border of the Alps the heterochromatin banding patterns were studied by Wetschnig (1983).

The present paper presents part of the author's studies on the variability of the genus Dactylis from Poland (biometrical and statistical studies, experimental cultures, and cytological studies). In this country diploid taxa of Dactylis are represented only by one subspecies - subsp. aschersoniana.

In the present paper the heterochromatin banding patterns of this taxon are described.

\section{MATERIAL AND METHUDS}

Three diploid population samples of Dactylis glomerata subsp. aschersoniana (Graebner) Thell. were studied:

1. Poznań province: Wiatrowiec near Wągrowiec, reservation "Dębina", coll. M. Mizianty, 01.07.1977.

2. Lublin province: Dys near Lublin, woody, loessic ravine, coll. L. Frey, 16.06.1978.

3. Kraków province: Niepołomicka Forest, between Chobot and Ispina, coll. M. Mizianty, 01.07.1978.

Root tips were pretreated with a $0.01 \%$ colchicine solution for 2 hours, and fixed in glacial acetic acid:ethanol (1:3). After fixation the Giemsa C-banding techniquè (Marks 1976) modified according Schwarzacher et al. (1980) was used. Root tips were softened in a $1 \%$ solution of pectinase plus $1 \%$ solution of cellulase in $0.01 \mathrm{M}$ sodium citrate buffer, after which they were squashed and the cover-slip was removed after freezing on dry ice; next the slides were treated with acetic acid $\left(45^{\circ} \%\right.$ at $58-60^{\circ} \mathrm{C}$ for 60 minutes), barium hydroxide (at room temp. for 15 minutes), and $2 \times \operatorname{SSC}$ (for 90 minutes at $60^{\circ} \mathrm{C}$ ). After a final wash in distilled water the slides were stained in 4\% Giemsa in phosphate buffer for 10-20 minutes. All slides were mounted in Euparal.

All measurements were taken on drawings at magnification $100 \times 10$. In order to restrict the errors in karyotype analyse: 1) All squashes, measurements and drawings were made by one person. 2) Measurements for each sample of population were made on 10 well-scattered metaphase plates. 3) The degree of contraction of the chromosomes was uniform and as high as possible.

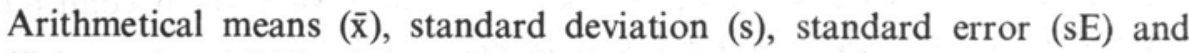
coefficient of variability (V) were established for the following characteristics of the chromosome:

1 - length of the longer arm,

$\mathrm{s}$ - length of the shorter arm,

$1+\mathrm{s}-$ absolute length of the chromosome, 
Table 1

samples of D. glomerata subsp. aschersoniana

\begin{tabular}{|c|c|c|c|c|c|c|c|c|c|c|c|c|c|c|c|c|c|c|c|c|c|c|c|c|c|}
\hline \multirow{2}{*}{ 点 } & \multirow{2}{*}{ 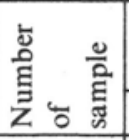 } & \multicolumn{4}{|c|}{ Absolute length, $\mu \mathrm{m}$} & \multicolumn{4}{|c|}{$\begin{array}{l}\text { Relative length } \\
\text { (L) }\end{array}$} & \multicolumn{4}{|c|}{$\begin{array}{l}\text { Arm ratio } \\
\text { (r) }\end{array}$} & \multicolumn{4}{|c|}{$\begin{array}{l}\text { Length of the shorter arm } \\
\text { (s) }\end{array}$} & \multicolumn{4}{|c|}{$\begin{array}{l}\text { Length of the longer arm } \\
\text { (l) }\end{array}$} & \multicolumn{4}{|c|}{$\begin{array}{l}\text { Length of the satellite } \\
\text { ( } t)\end{array}$} \\
\hline & & $\overline{\mathrm{x}}$ & $\mathrm{sE}$ & $s$ & $\mathrm{~V}$ & $\overline{\mathrm{x}}$ & $\mathrm{sE}$ & $\mathrm{s}$ & $\mathrm{V}$ & $\overline{\mathrm{x}}$ & sE & $\mathrm{s}$ & $\mathrm{V}$ & $\overline{\mathbf{x}}$ & $\mathrm{sE}$ & $s$ & $\mathrm{~V}$ & $\overline{\mathrm{x}}$ & $\mathrm{sE}$ & $\mathrm{s}$ & $\mathrm{V}$ & $\overline{\mathrm{x}}$ & $\mathrm{sE}$ & $\mathrm{s}$ & $\mathrm{V}$ \\
\hline \multirow[t]{3}{*}{ I } & 1 & 8.75 & 0.75 & 2.24 & 25.60 & 20.86 & 0.58 & 1.73 & 8.29 & 1.14 & 0.03 & 0.08 & 7.02 & 4.08 & 0.35 & 1.05 & 25.74 & 4.67 & 0.40 & 1.19 & 25.48 & 3.00 & 0.08 & 0.25 & 8.33 \\
\hline & 2 & 7.82 & 0.59 & 1.76 & 22.46 & 21.15 & 0.70 & 2.10 & 9.92 & 1.16 & 0.03 & 0.10 & 8.62 & 3.64 & 0.30 & 0.90 & 24.72 & 4.18 & 0.29 & 0.87 & 20.81 & 2.65 & 0.19 & 0.59 & 22.26 \\
\hline & 3 & 9.13 & 0.42 & 1.26 & 13.80 & 21.22 & 0.73 & 2.20 & 10.37 & 1.45 & 0.04 & 0.13 & 8.96 & 3.75 & 0.28 & 0.83 & 22.13 & 5.37 & 0.30 & 0.89 & 16.57 & 2.75 & 0.19 & 0.56 & 20.37 \\
\hline \multirow[t]{3}{*}{ II } & 1 & 8.35 & 0.70 & 2.11 & 25.27 & 19.91 & 0.51 & 1.54 & 7.73 & 1.13 & 0.03 & 0.08 & 7.08 & 3.92 & 0.29 & 0.87 & 22.19 & 4.43 & 0.41 & 1.24 & 27.99 & 2.75 & 0.23 & 0.70 & 25.45 \\
\hline & 2 & 6.86 & 0.54 & 1.60 & 23.63 & 18.55 & 0.74 & 2.22 & 11.96 & 1.33 & 0.07 & 0.22 & 16.54 & 2.95 & 0.28 & 0.85 & 28.81 & 3.91 & 0.32 & 0.98 & 25.06 & 2.62 & 0.21 & 0.63 & 24.04 \\
\hline & 3 & 8.25 & 0.19 & 0.56 & 6.79 & 19.18 & 0.47 & 1.41 & 7.35 & 1.45 & 0.04 & 0.12 & 8.28 & 3.37 & 0.18 & 0.55 & 16.32 & 4.88 & 0.09 & 0.26 & 5.33 & 2.50 & 0.12 & 0.35 & 14.00 \\
\hline \multirow[t]{3}{*}{ III } & 1 & 7.07 & 0.51 & 1.52 & 21.50 & 16.85 & 0.25 & 0.74 & 4.39 & 1.65 & 0.02 & 0.05 & 3.03 & 2.67 & 0.20 & 0.59 & 22.10 & 4.37 & 0.31 & 0.93 & 21.28 & & & & \\
\hline & 2 & 6.62 & 0.23 & 0.70 & 10.56 & 17.91 & 0.77 & 2.30 & 12.84 & 1.28 & 0.03 & 0.10 & 7.81 & 2.90 & 0.10 & 0.30 & 10.34 & 3.72 & 0.15 & 0.45 & 12.09 & & & & \\
\hline & 3 & 7.37 & 0.37 & 1.11 & 15.06 & 17.13 & 0.77 & 2.31 & 13.49 & 1.93 & 0.03 & 0.09 & 4.66 & 2.50 & 0.10 & 0.31 & 12.40 & 4.86 & 0.27 & 0.80 & 16.46 & & & & \\
\hline \multirow[t]{3}{*}{ IV } & 1 & 5.95 & 0.38 & 1.14 & 19.16 & 14.19 & 0.47 & 1.42 & 9.53 & 2.39 & 0.01 & 0.03 & 1.26 & 1.75 & 0.11 & 0.34 & 19.43 & 4.20 & 0.27 & 0.80 & 19.05 & & & & \\
\hline & 2 & 5.18 & 0.42 & 1.27 & 24.52 & 14.01 & 0.60 & 1.79 & 12.86 & 1.91 & 0.25 & 0.76 & 39.79 & 1.78 & 0.15 & 0.46 & 25.84 & 3.40 & 0.29 & 0.89 & 26.17 & & & & \\
\hline & 3 & 6.13 & 0.37 & 1.11 & 18.10 & 14.25 & 0.41 & 1.23 & 8.63 & 2.50 & 0.21 & 0.63 & 25.20 & 1.75 & 0.09 & 0.27 & 15.43 & 4.38 & 0.36 & 1.07 & 24.42 & & & & \\
\hline \multirow[t]{3}{*}{$\mathrm{v}$} & 1 & 5.10 & 0.42 & 1.27 & 24.90 & 12.16 & 0.39 & 1.18 & 9.70 & 2.19 & 0.12 & 0.37 & 16.89 & 1.60 & 0.13 & 0.38 & 23.75 & 3.50 & 0.32 & 0.97 & 27.71 & & & & \\
\hline & 2 & 4.20 & 0.24 & 0.71 & 16.90 & 11.36 & 0.38 & 1.14 & 10.03 & 2.23 & 0.15 & 0.46 & 20.62 & 1.30 & 0.11 & 0.33 & 25.38 & 2.90 & Q.14 & 0.44 & 15.17 & & & & \\
\hline & 3 & 4.51 & 0.11 & 0.32 & 7.10 & 10.48 & 0.22 & 0.65 & 6.20 & 2.99 & 0.14 & 0.42 & 14.05 & 1.13 & 0.07 & 0.20 & 17.54 & 3.38 & 0.15 & 0.44 & 13.02 & & & & \\
\hline \multirow[t]{3}{*}{ VI } & 1 & 3.59 & 0.11 & 0.32 & 8.90 & 8.56 & 0.72 & 2.17 & 25.35 & 2.07 & 0.07 & 0.20 & 9.42 & 1.17 & 0.04 & 0.11 & 9.40 & 2.42 & 0.07 & 0.22 & 9.09 & & & & \\
\hline & 2 & 3.48 & 0.18 & 0.55 & 15.80 & 9.41 & 0.24 & 0.72 & 7.65 & 1.88 & 0.20 & 0.61 & 32.44 & 1.21 & 0.24 & 0.72 & 30.58 & 2.27 & 0.12 & 0.36 & 15.85 & & & & \\
\hline & 3 & 4.13 & 0.22 & 0.66 & 15.98 & 9.60 & 0.35 & 1.06 & 11.04 & 1.99 & 0.10 & 0.57 & 28.64 & 1.38 & 0.12 & 0.36 & 26.09 & 2.75 & 0.17 & 0.50 & 18.19 & & & & \\
\hline \multirow{3}{*}{ VII } & 1 & 3.13 & 0.08 & 0.25 & 799 & 7.46 & 0.52 & 1.55 & 20.77 & 1.40 & 0.12 & 0.35 & 25.21 & 1.33 & 0.07 & 0.22 & 16.54 & 1.80 & 0.07 & 0.21 & 11.39 & & & & \\
\hline & 2 & 2.81 & 0.21 & 0.64 & 22.77 & 7.60 & 0.48 & 1.43 & 18.82 & 1.28 & 0.12 & 0.35 & 27.34 & 1.23 & 0.12 & 0.36 & 29.26 & 1.58 & 0.12 & 0.38 & 24.05 & & & & \\
\hline & 3 & 3.50 & 0.28 & 0.83 & 23.71 & 8.10 & 0.35 & 1.05 & 12.96 & 1.33 & 0.09 & 0.27 & 20.30 & 1.50 & 0.11 & 0.32 & 21.33 & 2.00 & 0.18 & 0.55 & 27.50 & & & & \\
\hline
\end{tabular}


$\mathrm{t}$ - length of the satellite (the value was added to the length of the arm to which the satellite was attached),

$\mathrm{r}-\operatorname{arm}$ ratio $\frac{1}{\mathrm{~s}}$,

$\mathrm{L}$ - relative length of the chromosome $-\frac{l+s}{\sum_{i=1}^{n=7}(l+s)} \times 100$,

$\mathrm{G}$ - for the karyotype as a whole - gradient of chromosomes length (length of the smallest chromosome : length of the largest chromosome) $\times 100$.

Chromosome nomenclature and analysis of the karyotype are given according to Levan et al. (1964-65).

Banding patterns nomenclature:

proximal band - near the centromere, terminal band - at the end of the chromosome arm, intercalar band - between the centromere and the end of the chromosome arm.

Additionally the bands were classified in two categories: intensively stained and weakly stained.

Chromosomes in the karyotype were arranged in the following order: first the satellite chromosomes followed by the remaining chromosomes according to the shortening of the longer arm.

\section{RESULTS}

The heterochromatin banding patterns of three population samples of D. glomerata subsp. aschersoniana are illustrated in three separate haploid karyograms (Fig. 1).

The numerical features of these karyotypes are given in a Table 1 .

The chromosomes of $D$. glomerata subsp. aschersoniana karyotype are differentiated in size. This is illustrated by the gradient of chromosome length, calculated for three population samples $\mathrm{G}_{1}=35.77, \quad(\mathrm{sE}=3.48$, $\mathrm{s}=10.46, \quad \mathrm{~V}=29.24 \%) ; \mathrm{G}_{2}=35.93(\mathrm{sE}=1.28, \mathrm{~s}=3.84, \mathrm{~V}=10.67 \%)$, $\mathrm{G}_{3}=38.33(\mathrm{sE}=1.70, \mathrm{~s}=5.09, \mathrm{~V}=13.28 \%$ ).

Figure 2 illustrates the distribution of all heterochromatin banding patterns observed in the individual pairs of chromosomes from I to VII. It must be stressed that in each pair the chromosome with a typical banding pattern is designated by the letter ,a”. The other banding patterns, designated by the letters „b", „c",... were observed by the author only very rarely (about $3-5 \%$ ).

Pair I is one of the longest median chromosomes in the karyotype:

length of the longer arm $-4.18-5.37 \mu \mathrm{m}$,

length of the sattelite $-2.65-3.00 \mu \mathrm{m}$,

length of the shorter arm $-3.64-4.08 \mu \mathrm{m}$, 


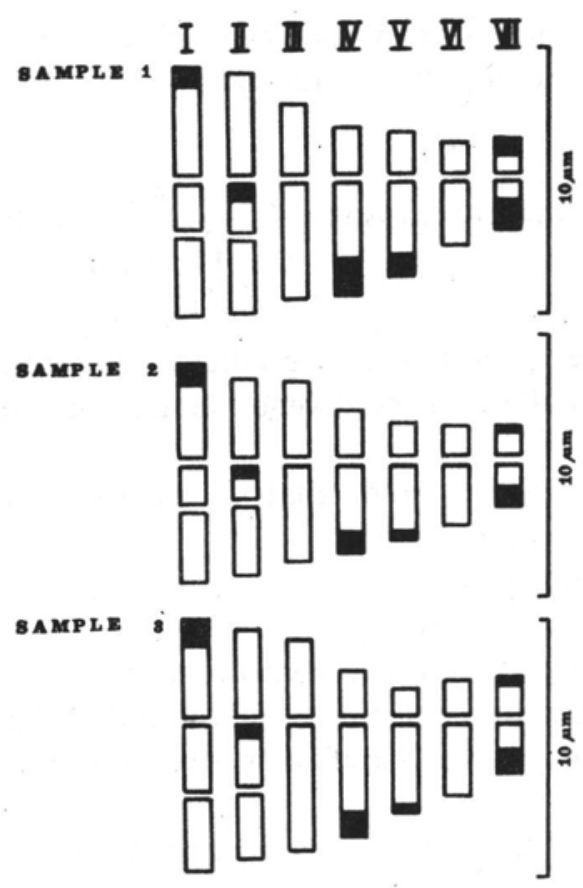

Fig. 1. Karyograms of three population samples of D. glomerata subsp. aschersoniana. I-VII - pairs of chromosomes

arm ratio - 1.14-1.45,

relative length $-20.86-21.22$.

The characteristic feature of this chromosome pair is the terminal heterochromatin band in the shorter arm $(0.67-1.05 \mu \mathrm{m})$ (Fig. 2Ia), looking sometimes like two bands lying side by side (Fig. 2Ib). Sporadically, an intercalar band (Fig. 2Ic) or small proximal band (Fig. 2Id) were observed on the same arm. On the part of the longer arm between the satellite and centromere frequently no bands were observed. An exceptionally weakly stained band (Fig. 2Ie) was present. On the satellite a terminal band (Fig. 2If), or sometimes an intercalar band (Fig. 2Ig), was present but this was very rare.

Pair II is also one of the longest median chromosomes in the karyotype:

length of the longer arm $-3.91-4.88 \mu \mathrm{m}$,

length of the satellite $-2.50-2.75 \mu \mathrm{m}$,

length of the shorter arm $-2.95-3.92 \mu \mathrm{m}$,

arm ratio - 1.13-1.45,

relative length $-18.55-19.91$.

These chromosomes are distinguishable from all the others in the karyotype by the intensively stained proximal heterochromatin band $(0.43-0.63 \mu \mathrm{m})$ in the longer arm of chromosome (Fig. 2IIa). On the shorter arm no 
heterochromatin patterns were observed. The satellite sometimes has a weakly stained terminal band (Fig. 2IIb) or, exceptionally, a proximal band (Fig. 2IIc).
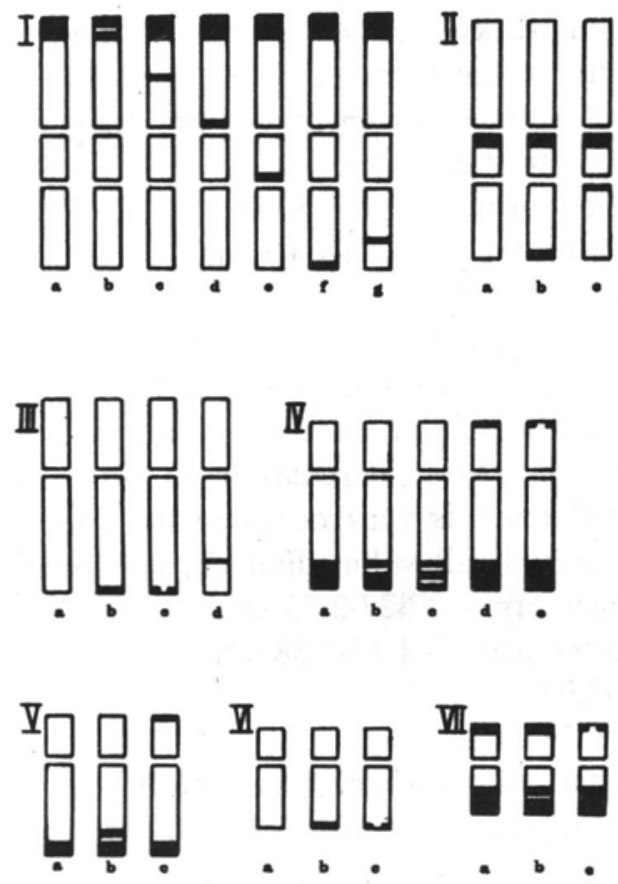

Fig. 2. Heterochromatin banding patterns in particular chromosme pairs. I-VII - pair of chŗomosomes; a - typical banding patterns; b-g - other, rare banding patterns

Pair III consists of the longest median chromosomes of the karyotype apart from the satellite chromosomes:

length of the longer arm $-3.72-4.86 \mu \mathrm{m}$,

length of the shorter arm $-2.50-2.90 \mu \mathrm{m}$,

arm ratio - 1.28-1.93,

realtive length $-16.85-17.91$.

A striking feature of this chromosomes is the absence of stained heterochromatin (Fig. 2IIIa). Exceptionally, a weakly stained terminal band may be observed on the longer arm (Fig. 2IIIb), sometimes visible only as two points (Fig. 2IIIc). On the same arm, an intercalar band is present very rarely (Fig. 2IIId).

Pair IV contains submedian chromosomes of medium size:

length of the longer arm $-3.40-4.38 \mu \mathrm{m}$,

length of the shorter arm $-1.75-1.78 \mu \mathrm{m}$,

arm ratio - 1.91-2.50,

relative length $-14.01-14.25$. 
The large terminal heterochromatin band $(0.88-1.40 \mu \mathrm{m})$ on the longer arm (Fig. 2IV a) is the characteristic feature of this pair. Exceptionally, it appears as two adjacent bands (Fig. 2IVb) or three smaller bands lying not far from each other (Fig. 2IVc). Occasionally on the shorter arm of the chromosome there is a weakly stained terminal heterochromatin band (Fig. 2IVd), sometimes only in the form of dots (Fig. 2IVe).

Pair V consists of submedian chromosomes slightly smaller than those of pair IV but also of medium size:

length of the longer arm $-2.90-3.50 \mu \mathrm{m}$,

length of the shorter arm $-1.13-1.60 \mu \mathrm{m}$,

arm ratio - 2.19-2.99,

relative length $-10.48-12.16$.

The chromosomes of pair $\mathrm{V}$ are characterized by a small terminal heterochromatin band $(0.30-0.75 \mu \mathrm{m})$ on the longer arm (Fig. 2Va). Exceptionally, on this same arm there appears intercalar band (Fig. 2Vb). On the shorter arm a weakly terminal band is very occasionally present (Fig. 2Vc).

Pair VI contains very small submedian chromosomes:

length of the longer arm $-2.27-2.75 \mu \mathrm{m}$,

length of the shorter arm $-1.17-1.38 \mu \mathrm{m}$,

arm ratio - 1.88-2.07,

relative length $-8.56-9.60$.

This pair is the second in the karyotype of D. glomerata subsp. aschersoniana without heterochromatin (Fig. 2VIa). Sporadically, a weakly stained terminal heterochromatin band is present on the longer arm (Fig. 2VIb), sometimes visible only as small dots (Fig. 2VIc).

Pair VII contains the smallest median chromosomes in the studied karyotype:

length of the longer arm $-1.58-2.00 \mu \mathrm{m}$,

length of the shorter arm $-1.23-1.50 \mu \mathrm{m}$,

arm ratio - 1.28-1.40,

relative length $-7.46-8.10$.

These chromosmes have a large content of heterochromatin. On the longer arm there is an intensively stained and very large terminal heterochromatin band $(0.87-1.06 \mu \mathrm{m})$ and on the shorter arm a smaller $(0.15-0.60 \mu \mathrm{m})$, weakly stained terminal band (Fig. 2VIIa). Sometimes the band on the longer arm appears as two bands (Fig. 2VIIb). In a few cases the band on the shorter arm takes the form of large dots (Fig. 2VIIc).

\section{DISCUSSION}

In general the karyotype and banding patterns of $D$. glomerata subsp. aschersoniana from Poland (Fig. 3) correspond with the karyotype of this taxon 


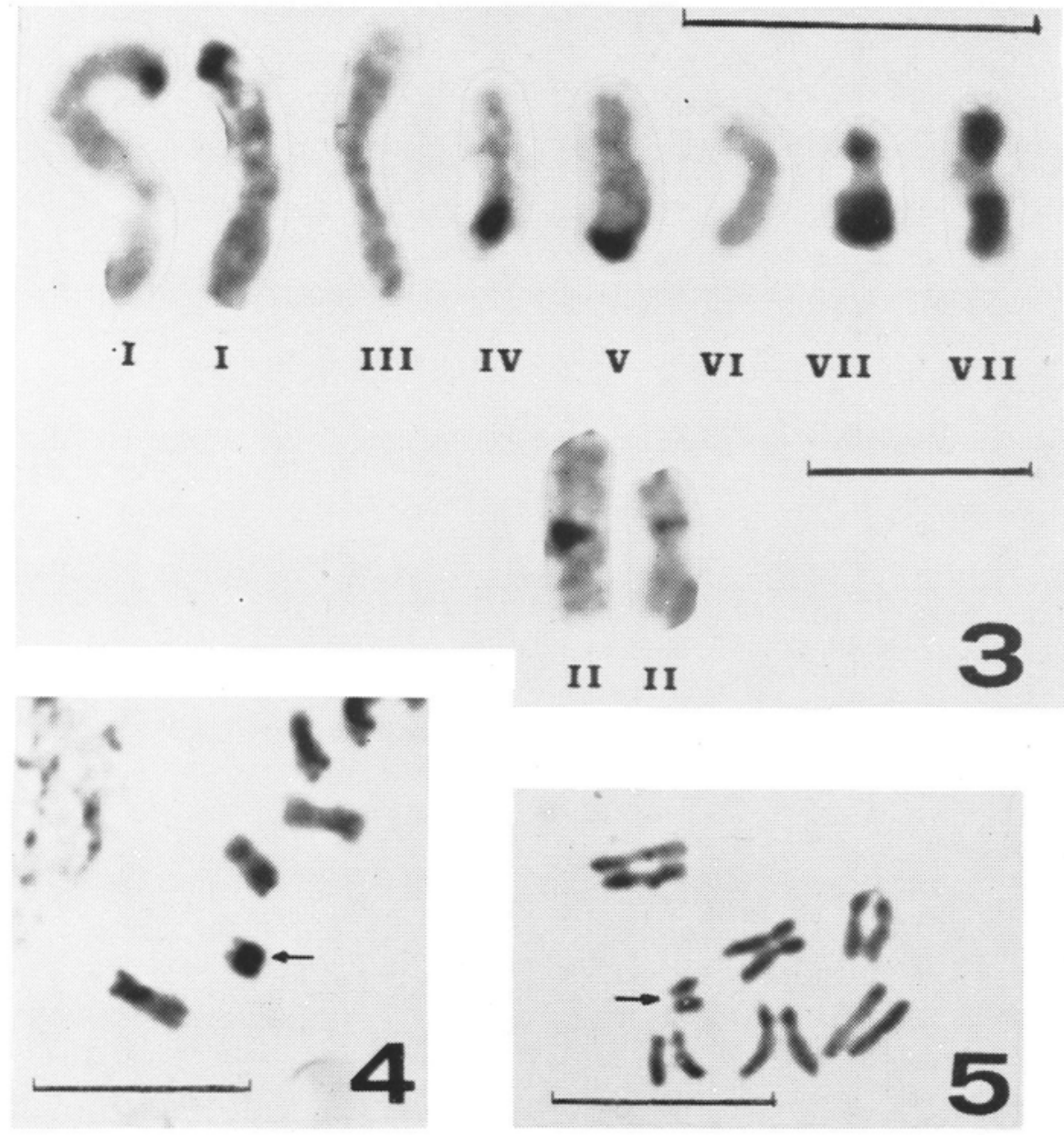

Fig. 3. Banding patterns in the selected chromosomes of D. glomerata subsp. aschersoniana from Poland. I-VIII - pairs of chromosomes. Scale $-10 \mu \mathrm{m}$

Figs. 4, 5. Differentiation of chromosome size in karyotype of D. glomerata subsp. aschersoniana from the Botanic Garden, Risskov-Aarhus, East Jutland, Denmark. Arrows show the smallest chromosomes. Scale $-10 \mu \mathrm{m}$ 
from the south-eastern border of the Alps determined by Wets,chnig (1983). However there are some differences.

SIMILARITIES

1. Two pairs of satellite chromosomes whose relative length is greatest, one pair with the terminal heterochromatin in the shorter arms and the other with proximal heterochromatin in the longer arms.

2. Two pairs of chromosomes without heterochromatin. One pair of median (third in respect of relative length) and the other of submedian chromosomes (almost the smallest in the karyotype).

3. Two pairs of submedian chromosmes with terminal heterochromatin in the longer arm. They differ from each other in the size of the heterochromatin bands.

DIFFERENCES

\section{The gradient of chromosome length (G).}

The chromosomes in the karyotype of Alpine plants are less differentiated in respect of length $(\mathrm{G}=75.50 ; \mathrm{s}=5.03)$ than those from Poland $(\mathrm{G}=36.68$; $\mathrm{s}=6.46$ ). The Alpine sample was compared with aggregated sample from Poland. Three samples from Poland were treated as a single (aggregated) sample because Two k-samples slippage tests (Puchalski 1980) at the 0.05 significance level did not show significant differences between these three samples $(m=2$, $\mathrm{k}=3, \mathrm{n}=10$ ).

For statistical analysis of differences between Alpine and Polish samples the statistical test cannot be used, because the size (n) of Alpine sample was unknown. Only $\overline{\mathrm{x}}$ and $\mathrm{s}$ were known. For this reason Alpine and Polish samples were compared by so-called rule of three $\sigma$ (Perkal 1958). From this comparision follows that they originate from populations differentiated in respect of value $\mathrm{G}$ (Fig. 6).

Studies of Dactylis chromosomes carried aut by Christ off and Moskova (1967), Fernandes and Queirós (1969), Kozhukharov and Nikolova (1975) and Titz (1965) suggest a differentiation of chromosome length in this karyotype. The present author also observed such differentiation in the material received from Prof. W. Titz from Vienna, i.e. D. glomerata subsp. aschersoniana from the Botanic Garden, Risskov-Aarhus, East Jutland, Denmark (Figs. 4, 5).

2. The content of heterochromatin in two pairs of submedian chromosomes.

Differences in the content of heterochromatin between two pairs of submedian chromosomes are as follows: the longer chromosome in the material studied by Wetschnig (1983) had a smaller quantity of heterochromatin than that in the material studied by the present author. It may be that 


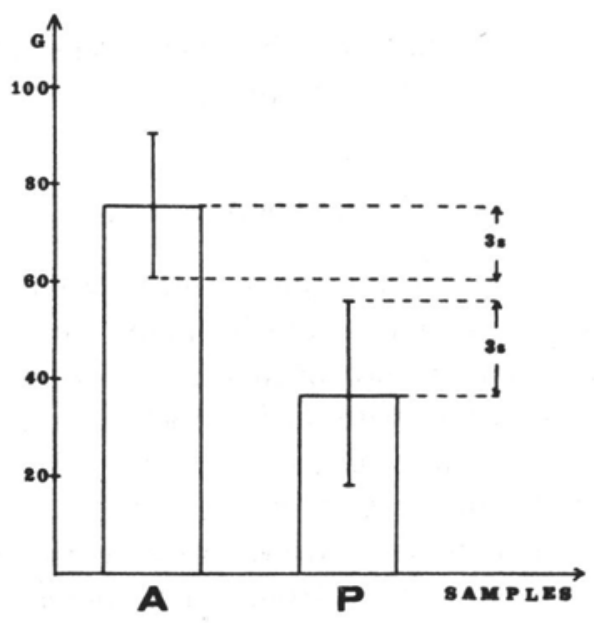

Fig. 6. Illustration of ,rule of three $\sigma$ ”, G - gradient of chromosome length, s - standard deviation, A-Alpine sample, $\mathrm{P}$ - Polish aggregated sample

in Wetschnig's material only a part of the heterochromatin was stained (see description of banding patterns of chromosome pairs IV and V).

Errors commited during analysis of heterochromatin banding patterns are the subject of papers by Bentzer and Landström (1975) and Shchapova (1977). It is also possible that this difference may arise from the causes mentioned by them. The different results were probably also caused by errors made during karyotype analysis as a result of different arrangement of these two chromosomes in the present author's and in Wetschnig's karyograms. Some errors which could be made during karyotype analysis were described by Bentzer et al. (1971) and Matern and Simak (1968). According to the above-mentioned authors, chromosome morphology depends on numerous factors, both biological and technical. Some of errors are inevitable.

\section{The content of heterochromatin in the smallest median chromosomes.}

According to Wetschnigs studies these chromosomes have terminal heterochromatin only in the longer arm, while in the material from Poland terminal heterochromatin appears in the longer as well in the shorter arm. The last-mentioned banding pattern varies from weakly stained dots to an intensively stained band (see description of banding patterns of chromosome pair VII).

These cytological investigation suggest that there exists some polymorphism of C-banding patterns in chromosome pair VII of the karyotype of D. glomerata subsp. aschersoniana. This polymorphism is not uncommon in other plant groups (Mizianty 1982).

In general, it may be stated that heterochromatin banding patterns in 
the karyotype of D. glomerata subsp. aschersoniana from the two studied areas are similar, with the exception of one in the smallest pair of median chromosomes.

\section{REFERENCES}

Bentzer B., Bothmer R., Engstrand L., Gustafsson M., Snogerup S., 1971. Some sources of error in determination of arm ratios of chromosomes. Bot. Not. 124: 65-74.

Bentzer B., Landström Th., 1975. Polymorphism in chromosomes of Leopoldia comosa (Liliaceae) revealed by Giemsa staining. Hereditas 80: 219-232.

Borrill M., 1961. Chromosomal status, gene exchange and evolution in Dactylis. 1. Gene exchange in diploids and tetraploids. Genetica 32: 94-117.

Borrill M., Jones K., 1961. Hexaploid Dactylis. Nature 190: 469-470.

Christoff M.A., Moskova R., 1967. Morphologische und Zytoembryologische untersuchungen über die Anlage und Entwicklung des Blütenstandes von Dactylis glomerata L. Wissenschaftliche Arbeiten Ser. Pflanz. (Sofia) 18: 137-147.

Doroszewska A., 1961. A comparative study on Dactylis slovenica Dom. and D. glomerata L. Acta Soc. Bot. Pol. 30: 775-802.

Doroszewska A., 1963. An investigation on the diploid and tetraploid forms of Dactylis glomerata L. ssp. Woronowii (Ovczinn.) Stebbins et Zohary. Acta Soc. Bot. Pol. 32: 113-130.

Fernandes A., Queirós M., 1969. Contribution á la connaissance cytotaxinomique des Spermatophyta du Portugal. I. Gramineae. Bol. Soc. Broter. (Ser. 2a). 43: 20-140.

Fiskesjö G., 1975. Chromosomal relationships between three species of Allium as revealed by C-banding. Hereditas $81:$ 23-32.

Kozhukharov S., Nicolova T., 1975. Cytotaxonomic studies on Bulgarian Gramineae. Bulg. Acad. Sci. In Honour of Acad. Daki Jordanov. Sofia, pp. 69-77.

Lavania U.C., Sharma A. K., 1980. Giemsa C-banding in Lathyrus L. Bot. Gaz. 141: 199-203.

Lavania U.C., Sharma A. K., 1983. Chromosome banding in evolutionary plant cytogenetics. Proc. Indian Acad. Sci. (Plant Sci.) 92: 51-79.

Levan A., Fredga K., Sandberg A., 1964-65. Nomenclature for centromeric position on chromosomes. Hereditas 52: 201-220.

Marks G. E., 1976. Variation of Giemsa banding patterns in the chromosomes of Anemone blanda. Chromosomes Today 5: 179-184.

Matern B., Simak M., 1968. Statistical problems in karyotype analysis. Hereditas 59: 281-290.

Mizianty M., 1982. Wzory prążkowe chromosomów roślinnych. I. Aktualny stan badań. Kosmos 5-6: 315-324.

Müntzing A., 1937. The effects of chromosomal variation in Dactylis. Hereditas 23: 113-235. Perkal J., 1958. Matematyka dla przyrodników i rolników. PWN, Warszawa, pp. 166-168.

Puchalski T., 1980. Statystyka. Wykład podstawowych zagadnień. PWN, Warszawa, pp. 301-303.

Schwarzacher G., Ambros P., Schweizer D., 1980. Application of Giemsa banding to Orchid karyotype analysis. Plant Syst. Evol. 134: 293-297.

Shchapova A., 1977. Method of Giemsa chromosome staining and its application to plant cytogenetics. In: The cytogenetics of hybrids, mutations and karyotype evolution. Khvostova V. (ed.), Publ. House .Nauka”, Siberian Branch, Novosibirsk, pp. 213-231.

Stebbins G. L., Zohary D., 1959. Cytogenetics and evolutionary studies in the genus Dactylis. I. Morphology distribution, and interrelationships of the diploid subspecies. Univ. California Publ. Bot. 31: 1-40. 
Titz W., 1965. Vergleichende Untersuchungen über den Grad der somatischen Polyploidie an nahe verwandten diploiden und polyploiden Sippen einschließlich der Cytologie von Antipoden. Oster. Bot. Zeitsch. 112: 102-172.

Werschnig W., 1983. Zur karyologie von Dactylis glomerata L., (Poaceae) am Südost-Rand der Alpen. Phyton 23: 271-305.

Wzory prażkowe chromosomów roślinnych. III. Dactylis glomerata subsp. aschersoniana (Graebner) Thell. z Polski

\section{Streszczenie}

Niniejsza praca jest fragmentem badań autorki nad zmiennością rodzaju Dactylis w Polsce. Opisano w niej heterochromatynowe wzory prążkowe chromosomów D. glomerata subsp. aschersoniana. Badania przeprowadzono na trzech próbach populacji z Polski. Analizowano zmienność wzorów heterochromatynowych. Porównano otrzymane wzory prążkowe z wzorami heterochromatynowymi dla $D$. glomerata subsp. aschersoniana z południowo-wschodnich Alp ustalonymi przez Wetschnig (1983). Przeprowadzone badania cytologiczne sugerują występowanie polimorfizmu wzorów prążkowych VII pary chromosomów w kariotypie D. glomerata subsp. aschersoniana. 